\title{
Interactions between bats and floral resources in a premontane forest, Valle del Cauca, Colombia
}

\author{
Catherine Mora-Beltrán¹ ${ }^{* 1}$ and Hugo Fernando López-Arévalo' \\ ${ }^{1}$ Grupo en Conservación y Manejo de Vida Silvestre, Instituto de Ciencias Naturales, Universidad Nacional de Colombia. Carrera \\ 30 n 45-03, edificio 425, oficina 110. Bogotá, Colombia. Email: cmorab@unal.edu.co (CMB), hflopeza@unal.edu.co (HLA). \\ ${ }^{*}$ Corresponding author
}

The study of interaction networks between species is a subject that has drawn increasing attention in recent decades, especially in investigations involving relationships between plants and pollinators or seed dispersers. In the Neotropics, bats of the subfamily Glossophaginae show morphological modifications for a specialized diet consisting of nectar and pollen, but opportunistic species belonging to other subfamilies that consume floral resources (nectar and pollen) have also been identified. This study describes for the first time the interactions between nectarivorous bats in the Andean region of Colombia from the identification of pollen associated with the bat species inhabiting the protected area "Reserva Forestal Bosque de Yotoco (RFBY)". Bats were captured with mist nets; a pollen sample was collected from each specimen by contact with glycerin gelatin, and pollen samples were mounted on slides. In addition, plant material of the blooming species that displayed the syndrome of chiropterophyly was collected to build a reference pollen collection. For the analysis, we used Levin's standardized niche breadth $\left(B_{A}\right)$, the relative frequency of resources (Fi), and the Resource Importance Value Index (RIVI). The interaction network was built and the NODF nesting algorithm was calculated to establish the degree of coupling within the network. In 44 loads of contact pollen for six species, three belonging to the subfamily Glossophaginae (Anoura caudifer, Glossophaga soricina and Choeroniscus godmani), we identified six palynomorphs from 7,971 pollen grains. The highest RIVI values correspond to three species of the genus Inga. The Levin's standardized niche breadth ( $\left.B_{A}\right)$ highlights Anoura caudifer and Glossophaga soricina as generalist species that take advantage of the availability of floral resources for consumption (Tables 2,3). The interaction network reveals a high nesting degree according to the value of the NODF algorithm of 86.67 (Figure 3 ). With four bat species, the RFBY has a high diversity of nectarivorous species relative to other localities across the Andean region of Colombia, despite the study area being a fragmented landscape; hence, this area is of critical importance for the local bat species, as it fulfills their food requirements. The bat species using the largest amount of resources in the community is Anoura caudifer; this finding differs from the results of other studies, where the genus Glossophaga has been reported as the dominant taxon in terms of resource use. Plants of the genus Inga and $O$. pyramidale are key resources for the nectarivorous bat species recorded, and this is probably also the case for other animals in the area; therefore, the inclusion of these species in the active restoration process will likely promote the establishment of a larger number of bats.

El estudio de redes de interacciones entre especies es un tema que ha tomado fuerza en las últimas décadas, especialmente en investigaciones que involucran relaciones entre plantas y dispersores de semillas o polinizadores. En el neotrópico, la subfamilia de murciélagos Glossophaginae presenta modificaciones morfológicas para una dieta especializada en el consumo de néctar y polen, aunque también se han identificado especies oportunistas pertenecientes a otras subfamilias que aprovechan recursos florales (néctar y polen). Este estudio describe por primera vez interacciones de murciélagos nectarívoros en la región Andina de Colombia a partir de la identificación del polen asociado a las especies de murciélagos presentes en el área protegida de la "Reserva Forestal Bosque de Yotoco (RFBY)". Se capturaron murciélagos con redes de niebla, a cada uno se le tomó una muestra de polen de contacto con gelatina glicerinada las cuales se montaron en láminas. Adicionalmente se colectó material vegetal de aquellas especies que estuvieran en floración y presentaran el síndrome de quiropterofilia para conformar la colección de polen de referencia. Para el análisis se empleó la amplitud de nicho estandarizada de Levin $\left(B_{A}\right)$, la frecuencia relativa de los recursos (Fi), el índice de valor de importancia del recurso (IVIR). Se construyó la red de interacciones y se calculó el algoritmo de anidamiento NODF para establecer el grado de acoplamiento de la red. En 44 cargas de polen de contacto para seis especies, tres de estas pertenecientes a la subfamilia Glossophaginae (Anoura caudifer, Glossophaga soricina y Choeroniscus godmani), se identificaron seis palinomorfos a partir de 7,971 granos de polen. Los valores más altos del IVIR corresponden a tres especies del género Inga. La amplitud de nicho estandarizada de Levin $\left(B_{A}\right)$, resalta a Anoura caudifer y Glossophaga soricina como especies generalistas que aprovechan la disponibilidad de recursos florales para su alimentación (Tablas 2, 3). La red de interacciones presenta un grado de anidamiento alto dado por el valor del algoritmo NODF de 86.67 (Figura 3). Con cuatro especies de murciélagos, la RFBY posee una alta diversidad de especies nectarívoras en comparación a las especies encontradas en otras localidades en la región Andina de Colombia pese a que se trata de un área fragmentada, por ello es una zona fundamental para estas especies ya que cubre los requerimientos alimenticios necesarios. La especie que más recursos utiliza en la comunidad es Anoura caudifer a diferencia de los resultados de otros estudios, donde el género Glossophaga es el que predomina en la utilización de los recursos. Tanto las plantas del género Inga como O. pyramidale, representan recursos importantes para las especies nectarívoras registradas como para otra fauna presente en la zona y probablemente al incluir estas especies en el proceso de restauración activa se puede promover el establecimiento de mayor cantidad de murciélagos.

Key words: Anoura caudifer; community; Glossophaga soricina; pollen; Yotoco.

(c) 2018 Asociación Mexicana de Mastozoología, www.mastozoologiamexicana.org 


\section{Introduction}

Mutualistic interactions between plants and their pollinators or dispersers form complex interdependence networks that lead to a dynamic stability in particular habitats (Bascompte 2007; Rohr et al. 2014). In studies of different taxonomic groups, heterogeneity and asymmetry have been identified as network features that provide stability to communities. In general terms, generalist plant species are linked to specialist pollinators and vice versa, shaping the physical structure of diversity (Bascompte and Jordano 2007; González et al. 2010). Data processing by managing complex networks facilitates the analysis of the coupling between species; this uses various metrics, including the degree of nesting that shows the level of structure for the network according to the number of connections and nodes (Bascompte et al. 2003). In this sense, the most common arrangement in a mutualist network involves the majority of species showing few connections and a small number of species with multiple connections, which contribute to maintain the attributes of the community (Bascompte et al. 2006; Olesen et al. 2008).

Most angiosperms require biological pollination, especially in the tropics, where an estimated $99 \%$ of the species in humid tropical forests are pollinated by animals (Bawa 1990). Only three to $11 \%$ of these pollinators correspond to birds and bats (Devy and Davidar 2003). Overall, approximately 528 species of angiosperms are recognized as being pollinated by bats (Fleming et al. 2009); in South America, 140 species have been identified as visited by bats for the consumption of nectar and pollen (Geiselman and Defex 2015). Worldwide, an estimated $7.7 \%$ of bat species visit flowers in search of food resources, including species with specialized morphological traits for the consumption of nectar (4.7\% of the world species) or opportunistic frugivorous species (Fleming et al. 2009; Geiselman and Defex 2015). In South America, the subfamilies Glossophaginae and Lonchophyllinae (family Phyllostomidae) show specialized morphological features for the consumption of nectar and pollen, including a long rostrum with reduced teeth and, in many cases, with spaces between them, long canines and long tongues with papillae or lateral grooves (Freeman 1995; Winter and von Helversen 2003). Separately, in the subfamilies Stenodermatinae, Phyllostominae, Rhinophyllinae, Glyphonycterinae and Carolliinae, frugivore and opportunistic omnivorous genera have also been reported that are capable of feeding on nectar and pollen: Artibeus, Carollia, Chiroderma, Phyllostomus, Platyrrhinus, Rhinophylla, Sturnira, Trinycteris, Uroderma and Vampyressa (Fleming et al. 2009).

Compared to the Old World, the Neotropics display a high taxonomic richness of pollinating species associated with the available resources, a fact that has been related to specialized ecological niches (Fleming and Muchhala 2008). The nectarivorous Neotropical bats show a shift in species composition along an altitudinal gradient, mainly due to the specialization of niches related to the morpho- logical adaptations of individual species (higher dietary specialization) and to the complexity of the community structure associated with the closer relationships between species (Owen 1990; Patterson et al. 1996; Fleming and Muchhala 2008). In line with the above, in intermediate and high zones of the Andean region (500 to 3,600 meters above sea level), the genus Anoura has diversified and specialized in the consumption of nectar and pollen (Koopman 1978; Mantilla-Meluk and Baker 2006; Fleming et al. 2009; Mantilla-Meluk et al. 2014), in contrast with low areas of the Andean region dominated by the genus Glossophaga, a species that inhabits an altitudinal range of 0 to 1,800 masl (Solari et al. 2013) that has less specialized morphological traits and diet.

In Colombia, few articles are available on the interactions between nectarivorous bats and the floral resources (nectar and pollen) consumed by them. In low areas (below 1,500 masl) of the Andean region, there is information available on the interactions between Glossophaga longirostris and columnar cacti in the Tatacoa desert (Ruiz et al. 1997), one study on the pollen carried by G. soricina in a suburban area of Cartagena, Bolívar (Lemke 1985), and one study about anthophilous bats of La Macarena, Meta (Muñoz-Saba et al. 1997). There is no information available on the potential interactions for the mountainous area of the Andean region, where a replacement of species and a lower species richness of nectarivorous bats occur. This study describes for the first time the interactions between nectarivorous bats in the Andean region of Colombia from the identification of pollen associated with bat species inhabiting the protected area Reserva Forestal Bosque de Yotoco (RFBY), located in Valle del Cauca, Colombia.

\section{Materials and Methods}

Study area. The protected area Reserva Forestal Bosque de Yotoco, in the department of Valle del Cauca, is located in the eastern slopes of the Western Cordillera of Colombia and includes the largest patch of premontane forest in this slope. It comprises an area of approximately 559 has spanning across an altitudinal range of 1,200 to 1,700 masl. Mean annual temperature is $20^{\circ} \mathrm{C}$ and mean annual precipitation is $1,500 \mathrm{~mm}$; the local climate regime is bimodal, with two rainy seasons (March to May and September to November) alternated with two dry seasons (June to August and December to February; Escobar 2001).

The RFBY is split in two areas by the BuenaventuraLoboguerrero-Buga highway; the zone under active restoration where this study was conducted is located in the high elevation area. The area under active restoration comprises $18 \%$ of the total area of the RFBY and includes a border zone with pastures used for livestock raising and a multi-purpose area that includes gardens and a compost heap (Figure 1). Two field trips were conducted, one in the dry season in June-July, and another in the rainy season in October 2016. 


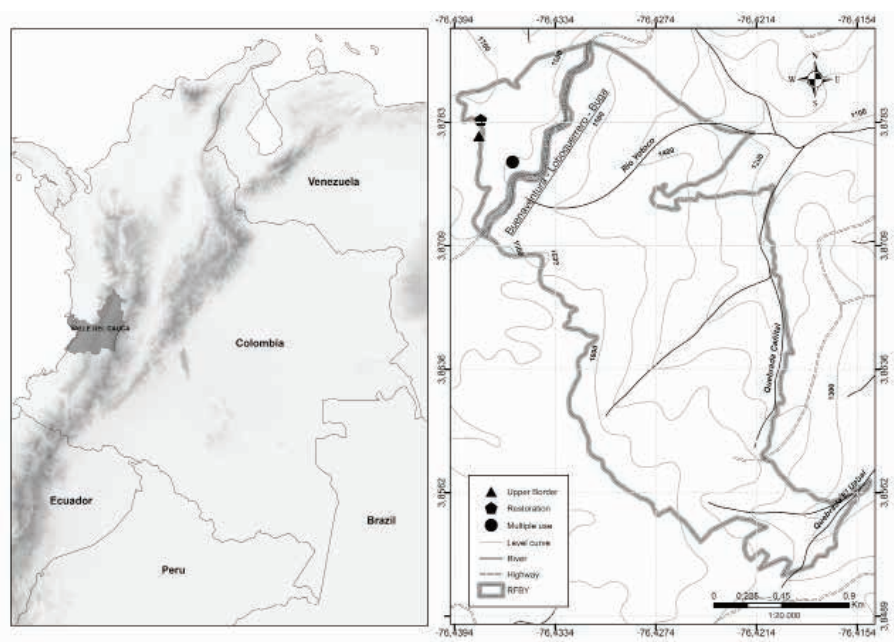

Figure 1. Map of the protected area "Reserva Forestal Bosque de Yotoco (RFBY)", Valle del Cauca, Colombia. The three areas sampled are shown (Upper Border, Restoration and Multiple Use) and the dotted line shows the Buenaventura-Loboguerrero-Buga highway that splits the total area of the RFBY (Perez-Moreno, 2018).

Capture and Sampling of Bat Specimens. Five to ten mist nets measuring $6 \mathrm{~m}, 9 \mathrm{~m}$ and $12 \mathrm{~m}$ long were used, keeping them open from 18:30 to 00:00 h. These nets were placed on the border as well as in the interior of the forest, considering the location of the flowering plants. Contact pollen samples were collected from the pelage of each specimen captured using glycerin gelatin prepared according to the technique of Beattie (cited by Voigt et al. 2009), sampling the rostrum, dorsum and wings. Samples were stored in tightly closed vials. Samples were mounted directly on slides without processing them through acetolysis to prevent loss of material, although this results in a lower resolution of the pollen wall.

From each specimen, data were recorded on reproductive status, age, weight and standard morphometry: total length ( $T L)$, tail length (TL), leg length (LL), ear length (EL), and forearm length (FL). Most specimens were identified in the field, and the rest were collected under the framework of the collection license of wild species of biological diversity for research purposes of the Universidad Nacional de Colombia. These were deposited in the Alberto Cadena Garcia collection of mammals, Instituto de Ciencias Naturales (ICN), Universidad Nacional de Colombia, with catalog numbers ICN 22767, 22792, 22795, 22796, 22798 to 22805 , 22809 to $22821,22829,22852,22860,22861,22862,22888$, 22896, 22898, 22905 to 22907,22920 to 22923,22926 to 22928, for subsequent identification following the keys of Griffiths and Gardner (2008), and the features described by Mantilla-Meluk and Baker (2006).

Collection of Reference Plant Material. The flowers collected were white or greenish with exerted stamens; corolla tubular or tubulose and perianth radially symmetrical or actinomorphic; nocturnal anthesis; rancid and moldy odor; nectar rich in hexoses and may contain sulfuric compounds for attraction following the description of the syndrome of chiropterophyly (Howe and Westley 1988; Von Helversen et al. 2000). Three vegetation transects located in different parts of the reserve were walked and flowering plants were identified by comparison with voucher specimens, taking into account those flowers that displayed the morphological traits mentioned above. Two transects were located in the area under active restoration and one at the upper border of the RFBY. In each transect, measuring $100 \mathrm{~m}$ long by $20 \mathrm{~m}$ wide, the flowering plant species were identified, and the flowering specimens were counted. In addition, trails and the border of the study area were walked to supplement the plant survey.

Palynological Analysis. To facilitate the identification of contact pollen collected from bat pelage, a reference collection was elaborated from flower samples including stamens and whole flowers seeking to have ripe pollen samples; these were preserved in $10 \%$ glacial acetic acid. For purposes of comparison and identification, these pollen samples were processed through acetolysis unlike the samples obtained from contact pollen according to the methodology established by Erdtman (1969), then mounted in slides and sealed with paraffin.

Palynomorphs in contact pollen samples were identified assisted with the reference pollen collection and the palynological atlas of Roubik and Moreno (1991), and the number of pollen grains per sample was determined. Each palynomorph was described including pollen unit, size, polarity, openings, scope, shape and sculpture to facilitate its identification (Punt et al. 2007).

Data Analysis. We calculated the sampling effort (hourmeter network), and capture success (number of captures per sampling unit) for each field trip, considering the total number of bats captured. For each bat species, the total number of grains in each sample was recorded, as well as the total number of individuals captured and the total number of palynomorphs found. Levin's stardardized niche breadth $\left(B_{A}\right)$ was used to set any preference in the use of the resources available for each bat species; this measure ranges from 0 to 1 depending on the predilection for resources (Krebs 1999).

We calculated the relative frequency of resources $(\mathrm{Fi}=$ $\mathrm{ni} / \mathrm{n} * 100$ ), where: $\mathrm{ni}=$ number of samples (slides) containing species $i ; n=$ total number of pollen slides analyzed. In addition, the Resource Importance Value Index (RIVI) was estimated using the formula by Amaya (1991) that calculates the value of resource use for each species of interest, then individual values are added up to give the importance value.

The degree of coupling and stability of the network was determined by calculating the NODF nesting algorithm (Almeida-Neto et al. 2008), whose value ranges from zero to 100 , attaining a maximum when the network is completely nested. The species interaction network was constructed with the statistical program R and the RStudio platform, using the Bipartite 2.02 package (Dormann et al. 2008); this array uses binary data to facilitate comparisons. 
A.
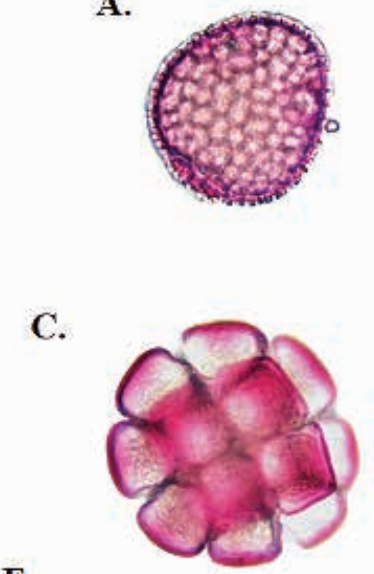

E.

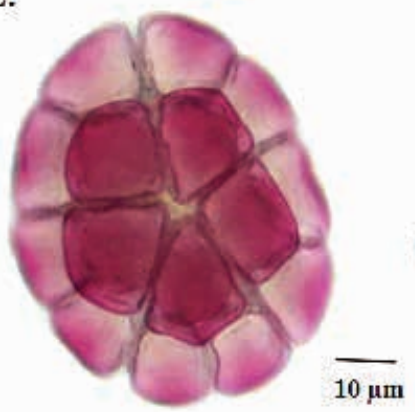

B.

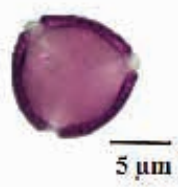

D.

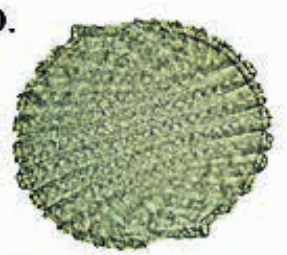

F.

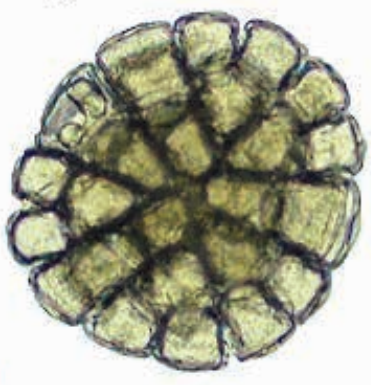

Figure 2. Palynomorphs found in contact pollen samples. A. Ochroma pyramidale. B. Clusiaceae. C. Inga cf. marginata. D. Acanthaceae. E. Inga cf. punctata. F. Inga cf. densiflora.

\section{Results}

A total of 238 individuals were captured, belonging to 21 bat species (Table 1); of these, 45 individuals (18.9\%) corresponded to nectarivorous species. Ten captured specimens were identified as Anoura caudifer, 33 as Glossophaga soricina and two as Choeroniscus godmani; the latter species represents a new record for the RFBY. A total sampling effort was 5,124-hour-net meter for the first trip, with a capture success of 0.34 , and 3,589.5 hours-net meter for the second, with a capture success of 0.26 . For nectarivorous species the capture success was 0.035 for the first trip and 0.091 for the second. Contact pollen was found in only 44 individuals ( $18.5 \%$ of the total capture), with 38 samples (86.4\%) obtained from nectarivorous bat species. The largest number of pollen samples was collected from $G$. soricina, with 28 samples in total, and only a single sample from S. Iudovici (Table 2). About resource use, the values of Levin's stardardized niche breadth $\left(B_{A}\right)$ ranged from 0.20 for S. Iudovici to 0.77 for A. caudifer.

From 7,971 pollen grains in the samples (Table 2), a total of six palynomorphs were identified in contact pollen (Figure 3), namely Inga cf. densiflora, Inga cf. punctata, Inga cf. marginata, Ochroma pyramidale, a single Clusiaceae and a single Acanthaceae. The majority of palynomorphs measure between 80 and $120 \mu \mathrm{m}$ in diameter; only the pollen of the Clusiaceae was small $(10 \mu \mathrm{m})$. Except for the pollen of Inga, all other grains showed a sculpture with some type of reticle in the exine. The relative resource frequency (Fi) yielded the highest value for the species I. cf. densiflora (Fi $=0.0069)$, and the lowest for the Clusiaceae $(\mathrm{Fi}=0.0002)$;
Table 1. Bat species and number of individuals of each species captured in the protected area Reserva Forestal Bosque de Yotoco (RFBY).

\begin{tabular}{|c|c|c|c|}
\hline Family & Subfamily & Species & $\begin{array}{c}\text { Individuals } \\
\text { captured }\end{array}$ \\
\hline \multirow[t]{18}{*}{ Phyllostomidae } & Carolliinae & Carollia brevicauda* & 35 \\
\hline & & Carollia castanea & 1 \\
\hline & & Carollia perspicillata & 67 \\
\hline & Desmodontinae & Desmodus rotundus & 27 \\
\hline & Glossophaginae & Anoura caudifer* & 10 \\
\hline & & Choeroniscus godmani* & 2 \\
\hline & & Glossophaga soricina* & 33 \\
\hline & Micronycterinae & Micronycteris hirsuta & 1 \\
\hline & Phyllostominae & Phyllostomus discolor & 1 \\
\hline & Stenodermatinae & Artibeus jamaicensis & 7 \\
\hline & & Artibeus lituratus* & 11 \\
\hline & & Chiroderma salvini & 1 \\
\hline & & Dermanura phaeotis & 18 \\
\hline & & Mesophylla macconnelli & 4 \\
\hline & & Platyrrhinus albericoi & 2 \\
\hline & & Sturnira bakeri & 1 \\
\hline & & Sturnira ludovici* & 3 \\
\hline & & Sturnira luisi & 3 \\
\hline \multirow[t]{3}{*}{ Vespertilionidae } & & Eptesicus chiriquinus & 3 \\
\hline & & Eptesicus cf. andinus & 3 \\
\hline & & Myotis riparius & 5 \\
\hline Total & & 21 & 238 \\
\hline
\end{tabular}

* Bat species from which contact pollen samples were collected.

these results are consistent with the highest (0.0119) and lowest (0.0003) Resource Importance Value Index (RIVI) for these same species (Table 3). For the Acanthaceae and $O$. pyramidale, although both were resources used by most bat species, their relative frequencies and RIVI are the lowest $(\mathrm{Fi}=0.0022 ; \mathrm{RIVI}=0.0047$ and $\mathrm{Fi}=0.0020 ; \mathrm{RIVI}=0.0044$, respectively) due to the few samples with pollen from these palynomorphs. The pollen from Clusiaceae was only found in one sample from $A$. caudifer; nonetheless, due to the abundance of grains in the sample (>100), it is considered as an important resource for the species (Table 3).

In the dry season, two blooming species, Psychotria brachiata and Piper setosum, and three fruiting species, Piper augustum, Miconia acuminifera and Nectandra macrophylla, were identified along the vegetation transects. In the rainy season, there was an increase in the number of flowering

Table 2. Bat species that used floral resources (nectar and pollen), with the respective number of total grains $(G)$, number of samples with pollen $(N)$, amount of resources used $(\mathrm{R})$, and Levin's standardized niche breadth $\left(\mathrm{B}_{\mathrm{A}}\right)$.

\begin{tabular}{lrrrr}
\multicolumn{1}{c}{ Species } & G & N & R & B $_{\text {A }}$ \\
\hline Artibeus lituratus & 7 & 2 & 3 & 0.40 \\
Carollia brevicauda & 3 & 3 & 3 & 0.40 \\
Sturnira ludovici & 5 & 1 & 2 & 0.20 \\
Choeroniscus godmani & 7 & 2 & 2 & 0.33 \\
Glossophaga soricina & 5,258 & 28 & 5 & 0.54 \\
\hline Anoura caudifer & 2,691 & 8 & 6 & 0.77 \\
\hline
\end{tabular}


plants to four species, Anthurium sp., Psychotria brachiata, Cyclanthus sp. and Philodendron montanum; fruiting plants of Beilschmiedia costaricensis were also observed. The reference collection included 17 plant species that were found in the transects and surveys in the RFBY. Of this collection, two species match palynomorphs found in contact pollen, I. cf. densiflora and I. cf. punctata.

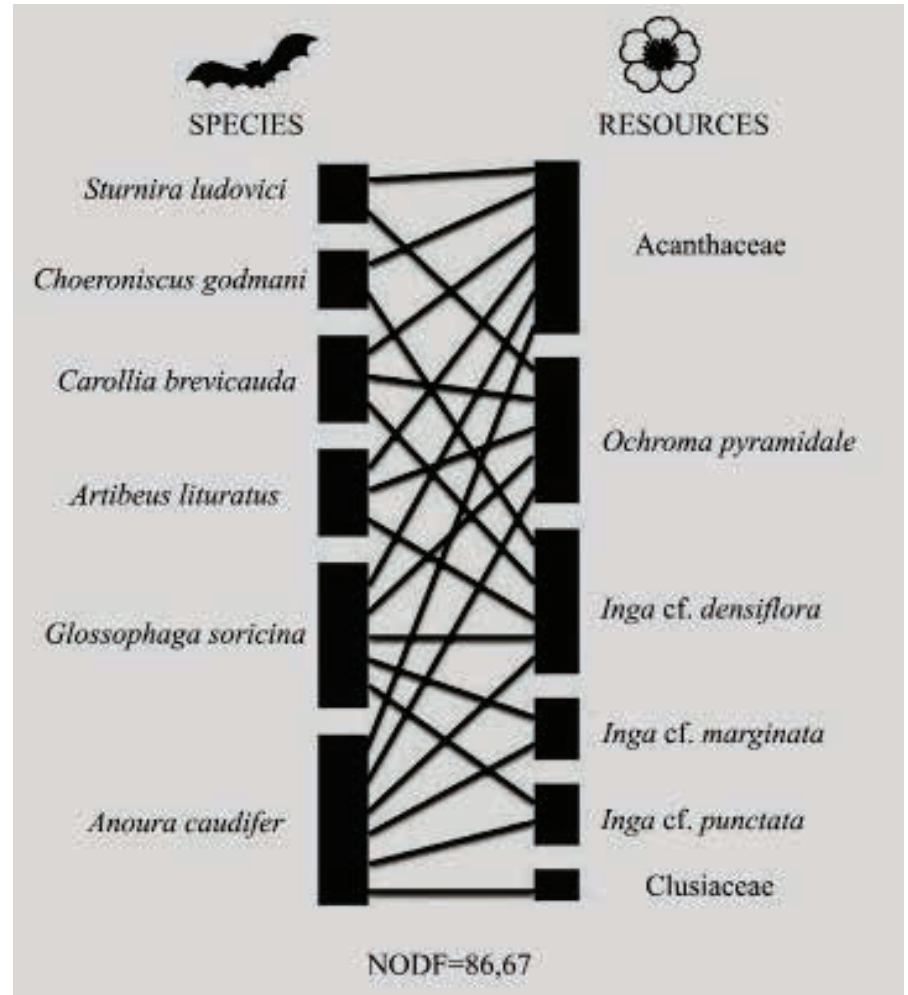

Figure 3. Interaction network between bats and floral resources (nectar and pollen) used in the protected area "Reserva Forestal Bosque de Yotoco (RFBY)", Valle del Cauca, Colombia. The nesting value according to the NODF algorithm is shown.

In the interaction network (Figure 3), the resources with more connections are the most important ones for the community in the season studied correspond to Acanthaceae, $O$. pyramidale and Inga species, mainly I. cf. densiflora, which was used by five bat species. As for bats, A. caudifer is the species using the greatest variety of resources, followed by G. soricina. C. godmani only used two resources, but this finding is inconclusive as it is based on only two samples. The remaining bat species used two or three resources that can be considered as sporadic records (< 10 grains; Table 2). The degree of nesting given by the NODF algorithm is 86.67 , reflecting the coupling between the most generalist species in the network and the species that have few connections.

Table 3. Floral resources identified from contact pollen, with the respective number of grains (G), total number of samples with presence of the palynomorph (NM), number of bat species that used the resource (EM), Relative Frequency (Fi), and Resource Importance Value Index (RIVI).

\begin{tabular}{lrrrrl}
\hline \multicolumn{1}{c}{ Resource } & G & NM & EM & Fi & IVIR \\
\hline Inga cf. densiflora & 3,864 & 34 & 5 & 0.0069 & 0.0119 \\
Inga cf. punctata & 274 & 25 & 2 & 0.0051 & 0.0081 \\
Inga cf. marginata & 510 & 23 & 2 & 0.0047 & 0.0074 \\
Acanthaceae & 85 & 10 & 6 & 0.0022 & 0.0047 \\
Ochroma pyramidale & 2,005 & 11 & 5 & 0.0020 & 0.0044 \\
\hline Clusiaceae & 1,235 & 1 & 1 & 0.0002 & 0.0003 \\
\hline
\end{tabular}

\section{Discussion}

The results described above provide an overview on the interactions between bats and floral resources observed in the RFBY. The degree of nesting in the network (NODF = 86.67) indicates that the nectarivorous species registered, particularly A. caudifer as a generalist species, contribute to the stability of interactions, a fact that may have ecological implications as to the pollination of the plants visited (Almeida-Neto et al. 2008; González et al. 2010). A review of studies conducted on bats in the same area (2011 MorenoMosquera; Velasquez-Carrillo 2015) and the catalog of vascular plants of the RFBY (Escobar 2001) identified 22 bat species that include nectar and pollen in the diet, and 25 plant species reported as visited by bats (Fleming et al. 2009; Geiselman and Defex 2015). Only three of these bat species are nectarivorous, Anoura caudifer, Anoura latidens and Glossophaga soricina: the rest are either frugivorous or omnivores that occasionally or rarely feed on pollen and nectar; in the case of plants, six genera, Cordia, Guzmania, Vriesea, Centropogon, Capparis, and Inga, are widely used by bats. In accordance with the above information, further sampling is needed to broaden our information about a larger number of bat species and their resources, in order to identify potential key species in the network, which interact with most species and connect different modules (Bascompte et al. 2003; Mello et al. 2015).

Although a smaller amount of pollen samples was obtained from A. caudifer relative to G. soricina, the former was the species using the largest number of resources (six) in the community, being the most generalist bat species in the network. This contrasts with the findings in other studies, where the genus Glossophaga has been reported as the dominant species in terms of resource use. In La Tatacoa desert, the bat species that maintains the closest relationship with the available resources, especially with columnar cacti, is G. longirostris (Ruiz et al. 1997). In Cartagena, Bolivar, G. soricina uses five resources in a suburban area (Lemke 1985), and in Serrania de La Macarena the only nectarivorous species reported that consumes nectar and pollen is $G$. soricina, which uses six available resources (Muñoz-Saba et al. 1997). The main diet of A. lituratus, S. ludovici and C. brevicauda is based on the consumption of fruits, and in montane forests these species are among the most abundant for this trophic guild (Estrada-Villegas et al. 2010; Moreno-Mosquera 2011). Therefore, it is considered that the use of nectar and pollen is occasional, consistent with the small amount of pollen grains found in samples. In the interaction network there is still uncertainty about the resources used by $A$. latidens in the study area, since this bat species was not captured in this study.

In the interaction network, the species of the genus Inga was an important resource for the bat community during the two seasons studied. In temperate climates with sufficient moisture, blooming plants of this genus occur throughout the year. Although these species have been reported to be pollinated by insects, especially lepidopter- 
ans (Koptur 1983), they are an essential resource for nectarivorous bats in the RFBY for their continued availability, as shown in other studies, particularly in humid tropical forests (Fleming and Muchhala 2008). Likewise, O. pyramidale is a generalist species used as a food resource for many species of animals, particularly mammals (Mora et al. 1999). The only individual observed in the study area is continuously used by primates and marsupials, although this plant is pollinated by nocturnal insects and mammals. It blooms from September to January in humid tropical forests (RojasRodríguez and Torres-Cordoba 2009), representing a seasonal resource; however, its phenology in Andean ecosystems remains unknown. Although the family Acanthaceae is the resource used by the largest number of species in the study area, its phenological and reproductive characteristics could not be determined in this study because the palynomorph is impossible to identify at the species level.

The abundance of pollen grains with reticulated sculpture is related to their adaptation to be transported by certain groups of animals (Amaya 1991; Stroo 2000). Pollen grains with a reticulated sculpture easily adhere to bat or bird pollinators, and in the case of plants of the genus Inga, there is a large production of pollen, hence increasing the probability of an effective pollination, as bats tend to carry a larger amount of pollen that birds (Muchhala and Thomson 2010).

The sampling conducted showed that RFBY has a high diversity of nectarivorous species relative to other localities across the Andean region of Colombia despite this being a fragmented area due to anthropogenic activities (Cantillo and Gómez 2004; Rodríguez et al. 2006). To date, four species have been registered in the RFBY, Anoura caudifer, $A$. latidens, Glossophaga soricina and the new record of $C$. godmani found in the present study (Moreno-Mosquera 2011; Velasquez-Carrillo 2015). Chavez-Landazury (2012), in La Mariposa reserve, located in Valle del Cauca, reports only $A$. caudifer in a premontane forest under a restoration process similar to the study area, at an altitude of 1,439 masl. Similarly, in a study on the diversity of bats along an altitudinal transect in the Tolima department, $A$. caudifer is reported as the only nectarívorous species in a strip between 1,000 and 2,000 masl (Bejarano et al. 2007). At altitudes above 2,000 masl in the Cordillera Central and the Cordillera Oriental of Colombia, only one species of the genus Anoura has been recorded (Rodríguez-Posada 2010; Perez-Torres and Ahumada 2004). These results are consistent with the predominance of the genus Anoura in intermediate and high altitudes in the Andean region, due to its diversification by niche specialization, which is related to the morphological adaptations of the species and the complexity of the community structure (Owen 1990; Patterson et al. 1996; Fleming and Muchhala 2008).

The increased success in the capture of nectarivorous species from the dry to the rainy season suggests that the species move following resource dynamics and availability; this has been observed mainly in dry tropical forests and arid ecosystems where bats are mobilized according to the availability of temporary resources (Fleming 1982; Cornejo et al. 2011). This phenomenon has been demonstrated in other species of nectarivorous bats in seasonal habitats such as dry areas (Ruiz et al. 1997; Moreno-Valdez et al. 2000). However, there is no clear evidence to date suggesting that the species found in this study and other nectarivorous species of Andean ecosystems do migrate (Rodríguez et al. 2012), although in humid tropical forests it is estimated that $A$. caudifer can travel up to $50 \mathrm{~km}$ in a single night in search of food (Von Helversen and Reyer 1984).

\section{Conclusions}

The RFBY is highly important for nectarivorous bat species, as it provides shelter and food in a fragmented landscape. It is a key area for the settlement of nectarivorous species, particularly A. caudifer and G. soricina, thus representing a suitable habitat for these species to be established and meet their food requirements.

The network constructed illustrated the interaction between six species of nectarivorous and frugivorous bats with six food resources identified. The species of the genus Inga and $O$. pyramidale were the resources most commonly used by the bat community over the season studied. Although A. caudifer visited all the plants recorded, it displayed selectivity or preference for some of them, such as I. cf. marginata, I. cf. punctata and the Acanthaceae during the study period.

To continue with the active restoration processes in the area, it is recommended to plant species of the genus Inga to promote the establishment of a larger number of nectarivorous bats, as these plants would represent a resource available throughout the year; in addition, their fruits are consumed by other mammals and birds. The same is also true for O. pyramidale, which represents an important food source for the local fauna despite its low abundance.

\section{Acknowledgments}

To the Universidad Nacional de Colombia, the collection of mammals "Alberto Cadena García", Instituto de Ciencias Naturales, the Grupo de Maztozoología of the Universidad Nacional de Colombia (GMUN), and the Laboratorio de Investigación en Abejas of the department of biology at the Universidad Nacional de Colombia (LABUN), for facilitating and allowing the conduct of this work. Thanks also to the Grupo en Conservación y Manejo de Vida Silvestre for the equipment provided to conduct this study. Also to the field assistants S. G. Acosta Morales, M. P. Henao, K. L. Velásquez Carrillo and S. Castellanos for their help in the field work. To the director of the protected area "Reserva Forestal Bosque de Yotoco (RFBY)" for allowing us to conduct this research, and to the reserve staff for their support and hospitality. To L. F. Liévano for his valuable comments and suggestions, and to H.Y. Pérez Moreno for the figure of the study area. Finally, to the reviewers for their valuable contributions and comments and to M. E. Sánchez Salazar for translated the manuscript into English. 


\section{Literature cited}

Almeida-Neto, M., P. Guimaräes, P. R. Guimaräes, R. D. Loyola, and W. ULRICH. 2008. A consistent metric for nestedness analysis in ecological systems: reconciling concept and measurement. Oikos 117:1227-1239.

AmaYA, M. 1991. Análisis palinológico de la flora del parque Amacayacu (Amazonas) visitada por colibríes (Aves: Trochilidae) (tesis de pregrado). Bogotá: Departamento de Biología, Facultad de Ciencias, Universidad Nacional de Colombia. Disponible en mamayam@unal.edu.co.

BAsCompte, J., P. JoRdANo, C. J. Melín, AND J. M. Olesen. 2003. The nested assembly of plant-animal mutualistic networks. Proceedings of the National Academy of Sciences 100:9383-9387.

BAsCompte, J., P. JoRdANo, AND J. M. Olesen. 2006. Asymmetric coevolutionary networks facilitate biodiversity maintenance. Science 312:431-433.

BASCOMPTE, J., AND P. JoRDANO. 2007. Plant-animal mutualistic networks: the architecture of biodiversity. Annual Review of Ecology, Evolution, and Systematics 38:567-593.

BAWA, K. S. 1990. Plant-Pollinator Interactions in Tropical Rain Forests. Annual review of Ecology and Systematics 21:399-422.

Bejarano-Bonilla, D. A., A. Yates-Rivas, and M. H. Bernal-Bautista. 2007. Diversidad y distribución de la fauna quiróptera en un transecto altitudinal en el departamento del Tolima, Colombia. Caldasia 29:297-308.

Cantillo, E. E., and A. F. Gómez. 2004. La Reserva natural de Yocoto: su vegetación leñosa. Colombia Forestal 8:75-93.

Chávez-Landazury, A. 2012. Composición y estructura de ensamblaje de murciélagos de sotobosque en La Reserva la Mariposa, Valle del Cauca. (Tesis doctoral). Cali: Programa Académico de Biología, Facultad de Ciencias Naturales y Exactas, Universidad del Valle.

Cornejo-Latorre, C., A. E. Rojas-Martínez, M. Aguilar-López, and L. G. Juárez-CAStILlo. 2011. Abundancia estacional de los murciélagos herbívoros y disponibilidad de los recursos quiropterófilos en dos tipos de vegetación de La Reserva de la Biosfera Barranca de Metztitlán, Hidalgo, México. Therya 2:169-182.

Devy, M. S., AND P. Davidar. 2003. Pollination systems of trees in Kakaachi, a mid-elevation wet evergreen forest in Westen Ghats, India. American Journal of Botany 90:650-657.

DORMANN, C. F., B. GRUBER, AND J. FrüND. 2008. Introducing the bipartite package: Analysing ecological networks. R News 8:8-11.

ERDTMAN, G. 1969. Handbook of Palynology. An Introduction to the Study of Pollen Grains and Spores. Munksgaard, Copenhagen, Denmark.

Escobar, E. 2001. Presentación de Yotoco "reserva Natural". Universidad Nacional de Colombia. Palmira, Colombia.

Estrada-Villegas, S., J. Pérez-Torres, and P. R. Stevenson. 2010. Ensamblaje de murciélagos en un bosque subandino colombiano y análisis sobre la dieta de algunas especies. Mastozoología Neotropical 17:31-41.

FLEMING, T. H. 1982. Foraging strategies of plant-visiting bats. Pp. 287-325 in Ecology of bats (Kunz T. H., ed). Plenum Press. New York, U. S. A.

Fleming, T. H., AND N. Muchiala. 2008. Nectar-feeding bird and bat niches in two worlds: pantropical comparisons of vertebrate pollination systems. Journal of Biogeography 35:764-780.
Fleming, T. H., G. Cullen, and W. J. Kress. 2009. The evolution of bat pollination: a phylogenetic perspective. Annals of botany 104:1017-1043.

Freeman, P. W. 1995. Nectarivorous feeding mechanisms in bats. Biological Journal of the Linnean Society 56:439-463.

Geiselman, C. K., T. I. Defex. 2015. Bat Eco-Interactions Database. www.batplant.org, version (20 january 2018).

GRIFFITHS T. A., AND A. L. GARDNER. 2008. Subfamily Glossophaginae Bonaparte, 1845. Pp. 224-236, in Mammals of South America, volume 1: marsupials, xenarthrans, shrews, and bats (Gardner, A. L., ed). University of Chicago Press. Chicago, U. S. A.

González, A. M., B. Dalsgaard, and J. M. Olesen. 2010. Centrality measures and the importance of generalist species in pollination networks. Ecological Complexity 7:36-43.

Howe, H. F., AND L. C.WestLey. 1988. Ecological relationships of plants and animals. Oxford University Press. New York, U. S. A. KoopmAN, K. F. 1978. Zoogeography of peruvian bats with special emphasis of the role Andes. American Museum Novitates 2651:1-33.

KoPTUR, S. 1983. Flowering phenology and floral biology of Inga (Fabaceae: Mimosoideae). Systematic Botany 8:354-368.

KreBS, C. J. 1999. Ecological Methodology. Segunda edición. Addison-Wesley Educational Publishers, Inc. Benjamin/ Cummings. Menlo Park, U. S. A.

Lemke, T. O. 1985. Pollen carrying by the nectar-feeding bat Glossophaga soricina in a suburban environment. Biotropica 17:107-111.

Mantilla-Meluk, H., and R. J. Baker. 2006. Systematics of small Anoura (Chiroptera: Phyllostomidae) from Colombia, with description of a new species. Occasional Papers Texas Tech University Museum 261:1-18.

Mantilla-Meluk, H., L. Siles, and L. F. Aguirre. 2014. Geographical and ecological amplitude in the nectarivorous bat Anoura fistulata (Phyllostomidae: Glossophaginae). Caldasia 36:373388.

Mello, M. A., F. A. Rodrigues, L. F. Costa, W. D. Kissling, Ç. H. ŞekercioĞlu, F. M. Marquitti, and E. K. Kalko. 2015. Keystone species in seed dispersal networks are mainly determined by dietary specialization. Oikos 124:1031-1039.

Mora, J. M., V. V. MÉndez, AND L. D. Gómez. 1999. White-nosed coati Nasua narica (Carnivora: Procyonidae) as a potential pollinator of Ochroma pyramidale (Bombacaceae). Revista de Biología Tropical 47:719-721.

Moreno-Mosquera, E. A. 2011. Papel de los murciélagos frugívoros como dispersores de semillas en La Reserva Forestal Natural de Yotoco, municipio de Yotoco, Colombia (Tesis de maestría). Bogotá: Departamento de Biología, Facultad de Ciencias, Universidad Nacional de Colombia. Disponible en hflopeza@unal.edu.co.

Moreno-Valdez, A., W. E. Grant, and R. L. Honeycutt. 2000. A simulation model of Mexican long-nosed bat (Leptonycteris nivalis) migration. Ecological Modelling 134:117-127.

MuchHALA, N., AND J. D. Thomson. 2010. Fur versus feathers: pollen delivery by bats and hummingbirds and consequences for pollen production. The American Naturalist 175:717-726.

Muñoz-SABA, Y., A. CAdenA, AND J. O. RanGel-CH. 1997. Ecología de los murciélagos antófilos del sector La Curia, Serranía La Macarena (Colombia). Revista de la Academia Colombiana de Ciencias 21:473-486. 
Olesen, J. M., J. Bascompte, H. Elberling, and P. Jordano. 2008. Temporal dynamics in a pollination network. Ecology 89:1573-1582.

OWEN, J. G. 1990. Patterns of mammalian species richness in relation to temperature, productivity, and variance in elevation. Journal of Mammalogy 71:1-13.

Patterson B. D., V. Pacheco, and S. Solari. 1996. Distributions of bats along an elevational gradient in the Andes of southeastern Peru. Journal of Zoology 240:637-658.

Pérez-Torres, J., and J. A. Ahumada. 2004. Murciélagos en bosques alto-andinos, fragmentados y continuos, en el sector occidental de la sabana de Bogotá (Colombia). Universitas Scientiarum 9:33-46.

Punt, W., P. P. Hoen, S. Blackmore, S. Nilsson, and A. L. Thomas. 2007. Glossary of pollen and spore terminology. Review of Palaeobotany and Palynology 143:1-81.

Rodríguez N. D., M. Armenteras, M. Morales, and M. Romero (eds.). 2006. Ecosistemas de los andes colombianos, segunda edición. Panamericana Formas e Impresos S.A. Instituto de investigaciones de Recursos Biológicos Alexander von Humboldt. Bogotá, Colombia.

Rodriguez-Posada, M. E. 2010. Bats from a forest in the Central Andes of Colombia with notes on their taxonomy and distribution. Caldasia 32:205-220.

Rodríguez-Rocha, M., C. Gómez, and H. Mantilla-Meluk. 2012. Murciélagos con evidencia de comportamiento migratorio en Colombia, uso de agroecosistemas y notas sobre su conservación. Pp. 97-128, in Agroecosistemas beneficiosos para las especies migratorias de Colombia. Informe final del Convenio 044 del 2012 entre SELVA: Investigación para la Conservación en el Neotrópico y la UPRA (Unidad de Planificación de Tierras Rurales, Adecuación de Tierras y Usos Agropecuarios) del Ministerio de Agricultura y Desarrollo Rural (Gómez C., J. M. Díaz, eds.). Ministerio de Agricultura y Desarrollo Rural. Bogotá, Colombia.

Rohr, R. P., S. SaAvedra, and J. Bascompte. 2014. Ecological networks. On the structural stability of mutualistic systems. Science 345:416-425.

Rojas-Rodríguez, F., and G. Torres-Córdoba. 2009. Árboles del Valle Central de Costa Rica: reproducción Balsa. Revista Forestal Mesoamericana Kurú 6:64-66.

Roubik, D. W., And P. Moreno. 1991. Pollen and spores of Barro Colorado Island (Panama). Volumen 36. Monographs in systematic botany from the Missouri Botanical Garden. Missouri, U. S. A.

Ruiz, A., M. Santos, P. J. Soriano, J. Cavelier, and A. Cadena. 1997. Relaciones Mutualísticas entre el murciélago Glossophaga longirostris y las Cactáceas Columnares en la Zona árida de La Tatacoa, Colombia. Biotropica 29:469-479.

SekerCioglu, C. H. 2006. Increasing awareness of avian ecological function. Trends in ecology and evolution 21:464-471.

Solarl, S., Y. Muñoz-Saba, J. V. Rodríguez-Mahecha, T. R. Defler, H. E. Ramírez-Chaves, and F. Trujillo. 2013. Riqueza, endemismo y conservación de los mamíferos de Colombia. Mastozoología Neotropical 20:301-365.

Stroo, A. 2000. Pollen morphological evolution in bat pollinated plants. Plant Systematics and Evolution 22:225-242.

Voigt, C. C., D. H. Kelm, B. J. Bradley, and S. Ortmann. 2009. Dietary Analysis of Plant-visiting Bats. Pp. 597, in Ecological and behavioral methods for the study of bats, segunda edición (Kunz, T. H., and S. Parsons, eds.). The Johns Hopkins University Press. Maryland, U. S. A.

Velásquez-CARRILlo, K. L. 2015. Inventario de mamíferos de La Reserva Forestal Bosque de Yotoco, Valle del Cauca, Colombia (trabajo de pregrado). Bogotá: Departamento de Biología, Facultad de Ciencias, Universidad Nacional de Colombia. Disponible en klvelasquezc@unal.edu.co.

Von Helversen, and H. U. Reyer. 1984. Nectar intake and energy expenditure in a flower visiting bat. Oecologia 63:178-184.

Von Helversen, O. L., L. Winkler, and H. J. Bestmann. 2000. Sulphurcontaining "perfumes" attract flower-visiting bats. Sensory, Neural, and Behavioral Physiology 186:143-153.

Winter, Y., And O. L. von Helversen. 2003. Operational tongue length in Phyllosthomid nectar-feeding bats. Journal of Mammalogy 84: 886-896.

\section{Associated editor: Guillermo D'Elia}

Submitted: Octuber 10, 2017; Reviewed: November 11, 2017;

Accepted: February 9, 2018; Published on line:April 5, 2018. 